\title{
Two new species of planthoppers from India (Hemiptera: Auchenorrhyncha: Delphacidae) in the genera Parasogata and Eoeurysa
}

\author{
Ramya N. ${ }^{1}$, Charles BARTLETT ${ }^{2} \&$ Naresh M. MESHRAM ${ }^{3, *}$ \\ ${ }^{1,3}$ Indian Council of Agricultural Research - Indian Agricultural Research Institute, \\ New Delhi 110012, India. \\ ${ }^{2}$ Department of Entomology and Wild Life Ecology, College of Agriculture and Natural Resources, \\ University of Delaware, Newark DE 19716, USA. \\ *Corresponding author: nmmeshram@gmail.com \\ 1Email: ramyanento@gmail.com \\ 2Email: bartlett@udel.edu \\ ${ }^{1}$ urn:1sid:zoobank.org:author:064ACDA0-ECAF-42E2-91D5-85DE937B8EEA \\ ${ }^{2}$ urn:lsid:zoobank.org:author:47CE21C6-6289-4AD4-90EB-3F03DE1D9BF3 \\ ${ }^{3}$ urn:1sid:zoobank.org:author:3B0F30C0-3391-4143-9169-5F996531AE72
}

\begin{abstract}
The genus Parasogata Zhou, Yang \& Chen, 2018 is here reported from India represented by the new species Parasogata sexpartita sp. nov. collected in a recent exploration and survey of delphacids from Nagaland in northeastern India. A second species of Eoeurysa Muir, 1913 from India, the new species Eoeurysa sagittaria sp. nov., was found in Rampur, Una, Himachal Pradesh. Both new species are described with illustrations, and a molecular identification is given with the $\mathrm{mtCOI}$ gene sequence. A modified key to species of the genera is also provided.
\end{abstract}

Keywords. Planthopper, morphology, distribution, identification, taxonomy.

Ramya N., Bartlett C. \& Meshram N.M. 2020. Two new species of planthoppers from India (Hemiptera: Auchenorrhyncha: Delphacidae) in the genera Parasogata and Eoeurysa. European Journal of Taxonomy 724 : 93-108. https://doi.org/10.5852/ejt.2020.724.1161

\section{Introduction}

The delphacid fauna of India remains incompletely investigated. Delphacidae Leach, 1815 is the second most speciose family of Fulgoromorpha Evans, 1946 with 2214 extant described species worldwide (after Cixiidae Spinola, 1839, with 2520 species) (Bourgoin 2019). The Indian fauna of Delphacidae includes 52 published species records (Distant 1906; Muir 1921; Joseph 1961, 1964; Mammen \& Menon 1972; Sharma \& Singh 1980, 1982; Kalode 1983; Asche 1985, 1990; Rao \& Chalam 2006; Nimisha 2008; Ramya \& Meshram 2019), plus an additional 13 species published in a PhD thesis (Mammen 1971). 
Here, we report on two new species of Delphacini Leach, 1815 (Delphacinae Leach, 1815) from the genera Parasogata Zhou, Yang \& Chen, 2018 and Eoeurysa Muir, 1913. Delphacini (Delphacinae) is the largest tribe of Delphacidae with 328 genera and 1631 species (Bourgoin 2019), including most of the economically important taxa (Wilson \& O'Brien 1987; Wilson 2005). The genus Parasogata was described from China with two species P. binaria Zhou, Yang \& Chen, 2018 and P. furca Zhou, Yang \& Chen, 2018 ( Zhou et al. 2018).

The genus Eoeurysa was established with the type species E. flavocapitata Muir, 1913 described from the "Malay Peninsula and South China" (Muir 1913: 249), later reported from sugarcane in India (Chatterjee 1971; Chatterjee \& Choudhuri 1979; Datta \& Ghosh 1979). A second species E. arudina Kouh \& Ding, 1980 from China (Yunnan) was subsequently added to the genus (Kuoh et al. 1980).

The molecular studies on delphacids gained a momentum with mitochondrial DNA nucleotide sequence data (mtCOI 504bp) generated by Dijkstra et al. $(2003,2006)$. These studies further paved the way for using different gene regions for the phylogenetic analyses of Delphacidae (Urban et al. 2010; Huang et al. 2017). MtCOI is one of the most promising genes for the species level identification and differentiation.

In this paper, we describe two new species of Delphacini, one species in the genus Parasogata, which also constitutes the first report of Parasogata from India, and another in the genus Eoeurysa. Distribution map for the new species is given (Fig. 6). We also report the mtDNA from the COI barcode region from these species and report on the implications of these data.

\section{Material and methods}

Morphological terminology follows that of Asche (1985) and Bartlett (2009). In the descriptions, the header 'male genitalia' is understood to include segments IX-XI. Photographs were taken with a Leica DFC 425C digital camera on a Leica M205FA stereozoom automontage microscope. Male genitalia dissections were carried out as described by Oman (1949) and Knight (1965). Type specimens of both species were deposited in the National Pusa Collection, Division of Entomology, ICAR-Indian Agricultural Research Institute, New Delhi, India (NPC). Distribution map for new species has been prepared using maps.google.com.

DNA was extracted from whole specimen by crushing the entire body, according to the manufacturer protocol, DNAsure Tissue Mini Kit with slight modification in the procedure. The mitochondrial cytochrome oxidase subunit I (mtCOI) gene was amplified for PCR products, using universal primers LCO1490: 5'-ggtcaacaaatcataaagatattgg-3'; HCO2198: 5'-taaacttcagggtgaccaaaaaatca-3' (Dietrich et al. 1997). The PCR protocol follows Hashmi et al. (2018). The polymerase chain reactions (PCR) were performed with $25 \mu \mathrm{l}$ reaction volumes in Ventri ${ }^{\circledR}$ 96-well thermal cycler (Applied Biosystems ${ }^{\circledR}$ Life Technologies). Cycling protocol was: 4 min hot start at $94^{\circ} \mathrm{C}, 35$ cycles of denaturation for $30 \mathrm{~s}$ at $94^{\circ} \mathrm{C}$, annealing for $60 \mathrm{~s}$ at $47^{\circ} \mathrm{C}$, elongation for $50 \mathrm{~s}$ at $72^{\circ} \mathrm{C}$ and a final extension at $72^{\circ} \mathrm{C}$ for $8 \mathrm{~min}$ in a $\mathrm{C} 1000^{\mathrm{TM}}$ Thermal cycler. The products were examined on a $2 \%$ agarose gel and visualized under UV using Alphaview ${ }^{\circledR}$ software ver. 1.2.0.1. The amplified products were sequenced at AgriGenome Pvt. Ltd (Cochin India). The quality sequences were assembled with BioEdit ver. 7.0.0 and deposited in NCBI GenBank. 


\title{
Results
}

\author{
Class Insecta Linnaeus, 1758 \\ Order Hemiptera Linnaeus, 1758 \\ Suborder Auchenorrhyncha Dumeril, 1806 \\ Infraorder Fulgoromorpha Evans, 1946 \\ Superfamily Fulgoroidea Latreille, 1807 \\ Family Delphacidae Leach, 1815 \\ Subfamily Delphacinae Leach, 1815 \\ Tribe Delphacini Leach, 1815
}

Genus Parasogata Zhou, Yang \& Chen, 2018

Parasogata Zhou, Yang \& Chen, 2018: 74. Type species Parasogata binaria Zhou, Yang \& Chen, 2018 (by original designation).

\section{Amended diagnosis}

Yellowish white to brown (Fig. 1A). Vertex, pronotum and mesonotum with uninterrupted white fascia. Vertex, frons, face, antennae yellowish brown to yellowish white. Pronotum and mesonotum yellowish white (Fig. 1C-D). Forewings and hindwings hyaline with prominent veins (Fig. 1B). Legs yellowish white. Abdomen yellowish orange (Fig. 1B). Head including eyes narrower than pronotum (Fig. 1C). Vertex subquadrangular, weakly anteriorly projected; anterior margin arched, submedian carinae uniting at apex; Y-shaped carina feeble (Fig. 1C). Frons with lateral margins weakly diverging ventrad (widest near frontoclypeal suture); much longer in middle line than wide at widest part; median carina forked at fastigium (Fig. 1D). Antennae cylindrical, scape longer than wide, pedicle more than twice length of scape (Zhou et al. 2018: figs 13-16). Pronotum relatively broad, lateral carinae nearly attaining hind margin (Fig. 1C). Spinal formula of hind leg 5-7-4. Post-tibial spur with 29-32 fine teeth along hind margin. Pygofer in profile wider ventrally than dorsally, lateral quadrangular areas strongly sclerotized, medioventral process absent. Diaphragm well developed, dorsal margin broadly convex, armature very weak (Fig. 2D-F). Aedeagus long, tubular, weakly upturned, with row of dorsal subapical processes (Fig. 2B-C; Zhou et al. 2018: figs 26, 52). Parameres (=gonostyli) simple (basal and apical angles not developed), widely divergent apically (Fig. 2H; Zhou et al. 2018: figs 27-28, 53-54). Suspensorium elongate (Zhou et al. 2018: figs 29, 55). Segment 10 collar-shaped, lateroapical angles produced into 1-2 paired processes (widely separated at base in caudal view) (Fig. 2G; Zhou et al. 2018: figs 24-25, 51).

\section{Remarks}

This genus is readily recognized by its large size and vertex, pronotum and mesonotum bearing an uninterrupted white fascia. The genus was compared with four similar genera by Zhou et al. (2018) and considered most similar to Sogata Distant, 1906 but distinguished by the phallus being up-curved, bearing a dorsal row of subapical processes.

\section{Key to the species of Parasogata Zhou, Yang \& Chen, 2018 based on males (modified from Zhou et al. 2018)}

1. Pronotum yellow (except median vitta); segment 10 bearing one pair of processes (Zhou et al. 2018: figs 50-51) P. furca Zhou et al., 2018

- Pronotum brown (except median vitta); segment 10 bearing two pairs of processes

2. Aedeagus with 10 subapical dorsal processes; segment 10 with two pairs of processes, ventral one about $2 \times$ as long as dorsal one (Zhou et al. 2018, figs 24-25) .............. P. binaria Zhou et al., 2018

- Aedeagus with 6 subapical dorsal processes; segment 10 with two pair of processes, ventral one about $4 \times$ as long as dorsal one (Fig. $2 \mathrm{~A}-\mathrm{C}, \mathrm{G})$ P. sexpartita sp. nov. 


\section{Parasogata sexpartita sp. nov. \\ urn:1sid:zoobank.org:act:6E735B03-F229-4D61-B1E6-BEF3AAC0F369}

Figs $1-2$

\section{Diagnosis}

Parasogata sexpartita sp. nov. can be recognized by yellowish orange to stramineous habitus (Fig. 1A) with uninterrupted white vitta from frons to tip of scutellum (Fig. 1C) and aedeagus with 6 subapical dorsal processes (Fig. 2A-C), segment 10 with two pairs of processes (Fig. 2G).

\section{Etymology}

The species name is derived from the Latin term 'sex', meaning 'six', plus 'partita', meaning 'parted', a reference to the number of subapical spines on the aedeagus. The specific epithet is intended to be feminine in gender to match apparent gender.

\section{Type material}

\section{Holotype}

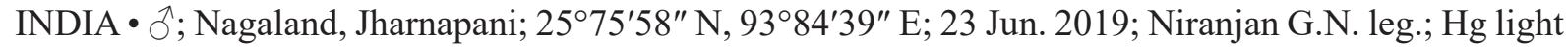
trap; NPC HEMT7.

\section{Paratype}

INDIA $・ 1$ त; same collection data as for holotype; NPC HEMT8.

\section{Description}

Measurements (mm). Male (holotype, NPC HEMT7) 4.6 long, 0.7 wide across eyes, 0.5 wide across hind margin of pronotum.

Colouration. Yellowish orange to stramineous. Vertex, pronotum and mesonotum with uninterrupted white vitta. Near-black bands follow lateral carinae from anterolateral compartments of vertex to frontoclypeal suture; median portion of frons white (continuation of dorsal vitta); clypeus pale medially, darker laterally. Genae orangish anteriorly, stramineous around (and including) antennae. Pronotum and mesonotum dark yellow. Forewings and hindwings yellow-hyaline with prominent black veins. Legs yellowish white. Abdomen yellowish orange (Fig. 1A-D).

MorPHOLOGY. Head including eyes $0.9 \times$ as wide as pronotum. Head weakly produced, vertex $0.3 \times$ as long as head width (including eyes) (Fig. 1A, C). Fastigium elliptical in lateral view (Fig. 1B). Frons longer than wide, lateral margins smoothly diverging to frontoclypeal suture, widest at apex; median carina forked at level of compound eyes. Clypeus as wide as frons basally, rostrum reaching mesocoxae. Antennae terete (Fig. 1D). Pronotum $3.2 \times$ as wide as long, anterior margin truncate behind vertex, posterior margin broadly convex; lateral carinae diverging, not reaching hind margin. Mesonotum $1.1 \times$ as wide as long; carina not conspicuous, obsolete before hind margin, lateral carinae weakly diverging (Fig. 1C). Forewings with $\mathrm{R}$ fork proximate to $\mathrm{CuA}$ fork; cell formed between fork of $\mathrm{R}$ and nodal line longer than that of cubitus; clavus long, reaching wing margin past basal $3 / 4$ of wing (approximately at nodal line); fork of Pcu $+1 \mathrm{~A}$ in basal $1 / 3$ of wing; branching pattern: RA unbranched, RP 2-branched $\left(\mathrm{RP}_{1+2}, \mathrm{RP}_{3+4}\right)$, MP unbranched, CuA 2-branched.

Male genitalia (Fig. 2). Pygofer in lateral view approximately quadrangular (Fig. 2F), anterior margin nearly truncate, caudal margin convexly rounded (in lateral view), $1.2 \times$ as long as wide; margins of opening rounded (not carinate). Diaphragm well developed, dorsal margin concave, armature weak (Fig. 2D). Parameres diverging, rather sinuate, $6.1 \times$ as long as wide; widest subapically, apically acute (Fig. 2H). Aedeagus $8 \times$ as long as wide; shallow tubular, dorso-basally concave, subapically ornamented 

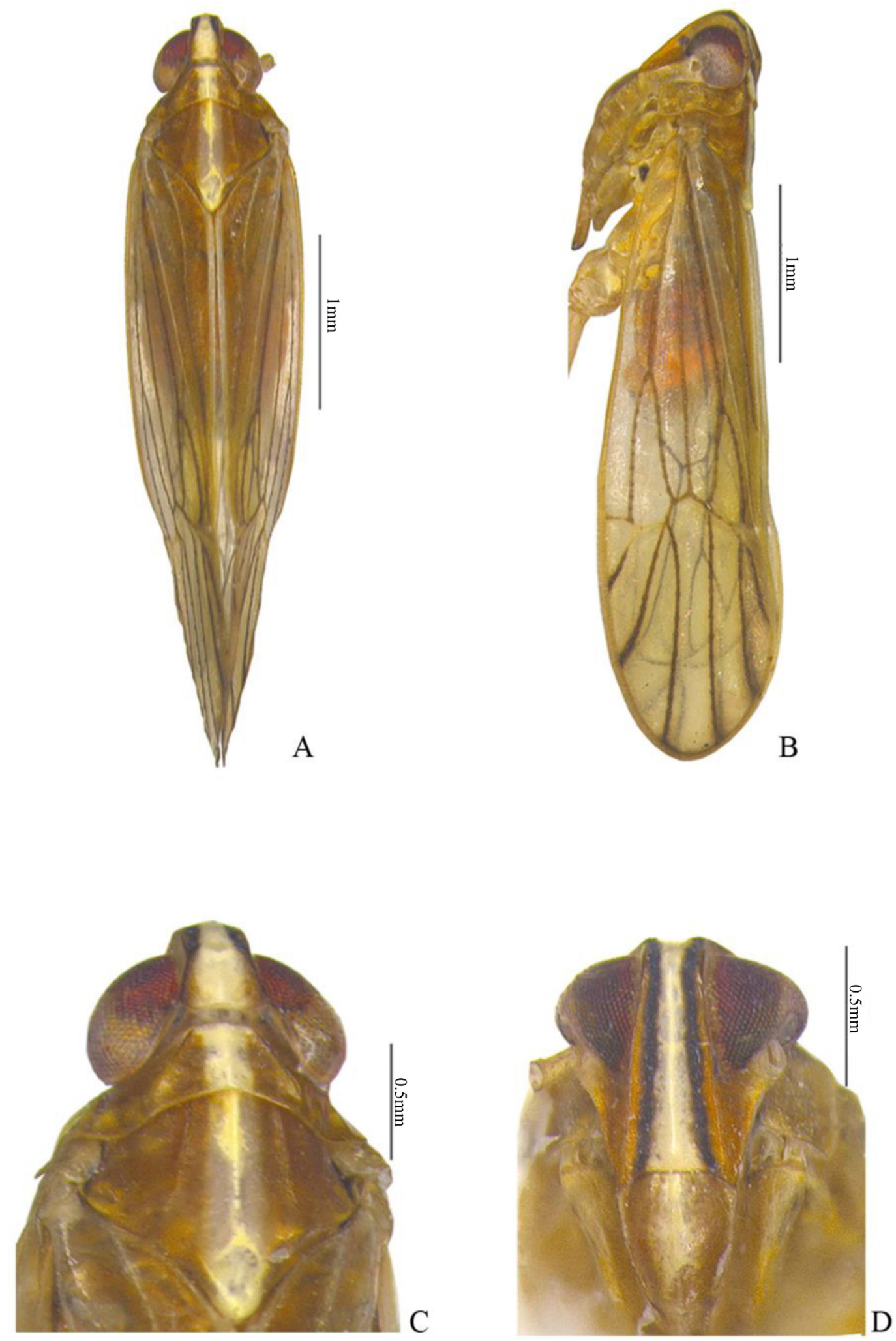

Fig. 1. Parasogata sexpartita sp. nov., holotype $\widehat{\partial}$ (NPC HEMT7). A. Habitus, dorsal view. B. Habitus, lateral view. C. Head, pro- and mesonotum, dorsal view. D. Head, ventral view. 

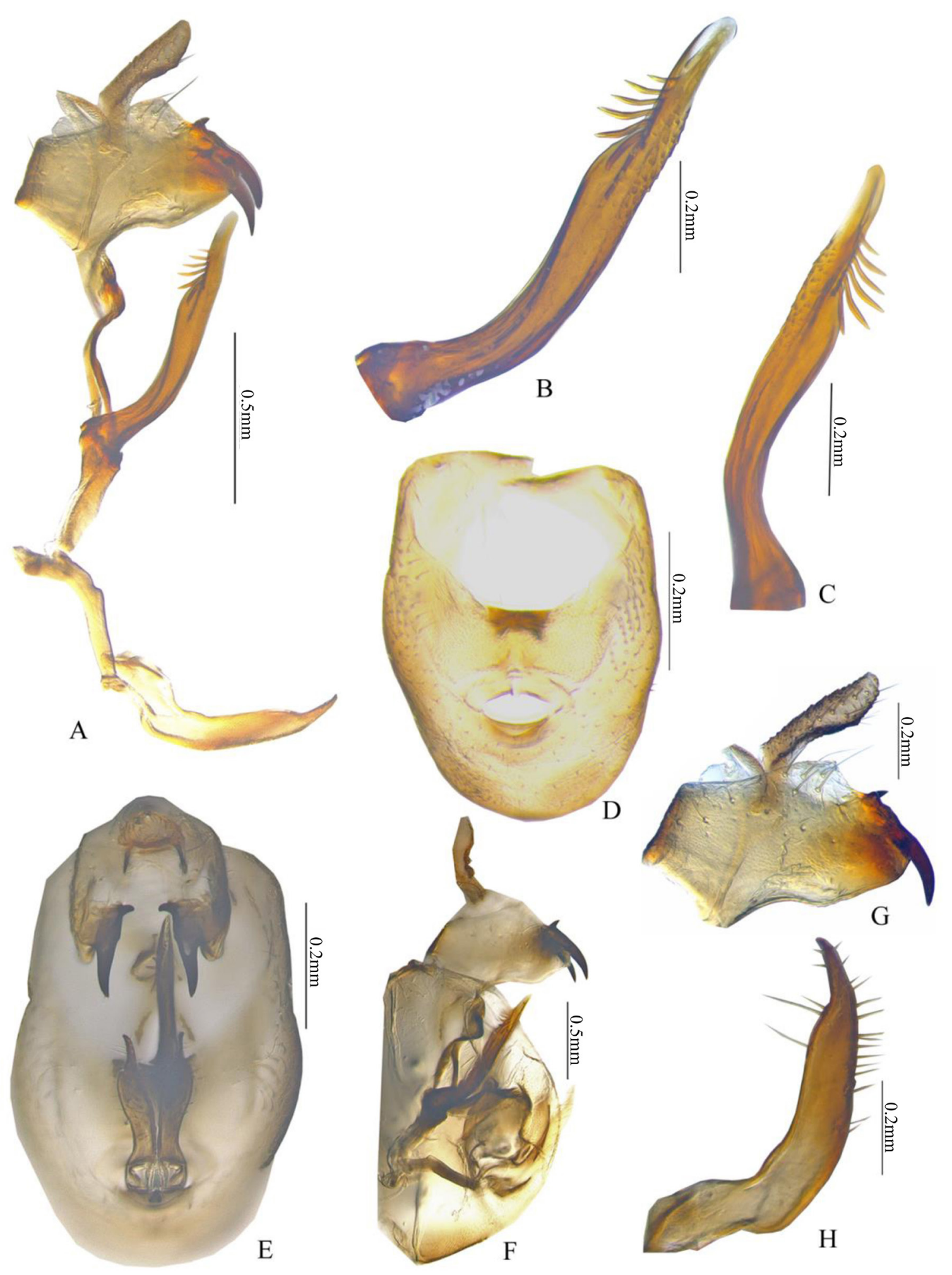

Fig. 2. Parasogata sexpartita sp. nov., male genitalia, holotype (NPC HEMT7). A. Aedeagal complex. B. Aedeagus, left view. C. Aedeagus, right view. D. Pygofer, caudal view. E. Male genitalia, caudal view. F. Male genitalia, lateral view. G. Segments 10 and 11. H. Paramere, lateral view. 
RAMYA N. et al., On two new species of Delphacini from India

with six radiating spines dorsally; apically recurved with dorsal gonopore (Fig. 2A-C). Segment 10, including segment $11,0.7 \times$ as long as wide (in lateral view) with two pairs of latero-apical pointed processes (dorsal tooth-like, ventral more elongate and directed ventrad); segment 11 long (Fig. 2G).

\section{Molecular data}

The DNA barcode fragment (mtCOI $\sim 650 \mathrm{bp}$ ) sequence was submitted to NCBI GenBank with accession number MN787519.

\section{Remarks}

This species is similar to P. binaria and can be distinguished by an aedeagus with six radiating spines (Fig. 2B-C) (vs ten in binaria) subapically and dorsal gonopore.

A peculiar aspect of the forewing venation is that the MP vein bends sharply at the nodal line, and it is not entirely clear whether it is angled toward the leading or trailing portion of the wing, a matter that could change the interpretation of the vein branches. Both previously described species of Parasogata appear to have the $\mathrm{RP} 3$-branched $\left(\mathrm{RP}_{1+2}, \mathrm{RP}_{3}, \mathrm{RP}_{4}\right)$.

There are no host associations reported for any species of Parasogata.

Genus Eoeurysa Muir, 1913

Eoeurysa Muir, 1913: 249. Type species Eoeurysa flavocapitata Muir, 1913 (by monotypy).

\section{Amended diagnosis}

Habitus colouration varies from near black (in male E. flavocapitata) to near white. Body distinctly dorsoventrally flattened (Fig. 3A-C). Head including eyes narrower than pronotum, projecting slightly in front of eyes. Vertex broad, narrowed anteriorly, as long as wide at base, Y-shaped carina distinct, apically converging at fastigium (Fig. 3D); fastigium rather angled (Fig. 3C) (appearing carinae when viewed from ventral aspect). Frons broad, lateral margins arched, slightly longer in middle line than wide at widest part, widest somewhat above frontoclypeal suture, median carina prominent and forked at fastigium. Basally clypeus as wide as apex of frons on dorsal margin. Rostrum reaching to mesocoxae (Fig. 3E). Ocelli present. Antennae terete, scape about as long as wide, pedicel exceeding $2 \times$ scape; surpassing frontoclypeal suture (Fig. 3D-E). Pronotum broad, lateral carinae attaining hind margin (Fig. 3D). Spinal formula of hind leg 5-7-4. Post-tibial spur with 17-19 fine teeth. Pygofer with laterodorsal angles not produced, in posterior view with opening rather quadrangular, appearing wider than long, medioventral process absent; diaphragm relatively weak, moderately wide, dorsal margin convex, protruding into a plate (Fig. 4B, D, G). Phallus tubular, approximately straight (Fig. 4C). Suspensorium elongate quadrangular, circular at ventral half. Segment 10 (anal segment) ring-like with short latero-apical processes (Fig. 4A).

\section{Remarks}

The genus can be distinguished by the depressed shape of the body (reminiscent of Eumetopina Breddin, 1896), and the broad, apically converging vertex. Eoeurysa is similar to Eumetopina, although the latter genus has a broader frons and displays processes on the medioventral portion of the pygofer opening.

\section{Biology}

Host associations of the genus are giant cane (Arundo donax L.) for Eoeurysa arundina Kuoh \& Ding, 1980 (Kuoh et al. 1980) and sugarcane (Saccharum sinense Roxb. and S. officinarum L.) for Eoeurysa flavocapitata (Chatterjee 1971; Wilson 1987; Wilson et al. 1992; Ding 2006). 


\title{
Key to the species of Eoeurysa Muir, 1913 (revised from Yang 1989)
}

1. General colouration mostly dark brown; vertex nearly as broad as long on midline (Yang 1989: fig. 110A); males with parameres nearly parallel-sided (not expanded medially, Yang 1989: fig. 110E); aedeagus lacking basal process (bearing flattened projection near midlength (Yang 1989: fig. 110J)

E. flavocapitata Muir, 2013

- General colouration pale (except clypeus and adjacent parts); vertex longer in midline than broad; male with parameres expanded medially; aedeagus with elongate process off dorso-basal portion 2

2. Clypeus dark (Yang 1989: fig. 111B); parameres very broad medially; aedeagus with 7-8 dorsal teeth (Yang 1989: fig. 111E, H)

E. arundina Kuoh \& Ding, 1980

- Clypeus pale yellowish (Fig. 3E); parameres modestly expanded medially, in lateral view with mediolateral process (Fig. 4E-F); apex of aedeagus sagittate, lacking dorsal teeth (Fig. 4C)

E. sagittaria sp. nov.

\author{
Eoeurysa sagittaria sp. nov. \\ urn:Isid:zoobank.org:act:EA1BE8CB-8138-4643-A8B9-DE75946E422D
}

Figs $3-5$

\section{Diagnosis}

Body dorsoventrally flattened, colouration creamy white to pale yellow, without dark markings (Fig. 3A). Vertex longer than broad (Fig. 3D). Male with parameres simple, sinuate, weakly expanded medially (Fig. 4E), in lateral view with mediolateral process (Fig. 4F). Aedeagus tubular, approximately straight, with strong, elongate, dorso-basal process, apex sagittate (Fig. 4C). Segment 10 with single caudal process (Fig. 4D).

\section{Etymology}

The species name comes from the Latin word 'sagittaria', meaning 'arrow', in reference to the arrowhead shape of the apex of the aedeagus. The specific epithet is feminine in gender to match the apparent gender of the genus.

\section{Type material}

\section{Holotype}

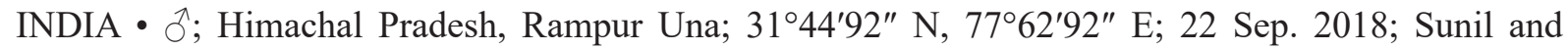
G.N. Niranjan leg; light trap; NPC HEMT9.

\section{Paratypes}

INDIA 4 \% ; same collection data as for holotype; NPC HEMT10 to HEMT13• 7 q ; same collection data as for holotype; NPC HEMT14 to HEMT20.

\section{Description}

Measurements (mm). Male (holotype, NPC HEMT9) 3.7 long, 0.6 wide across eyes, 0.5 wide across hind margin of pronotum. Female (paratype, NPC HEMT14) 3.9 long, 0.6 wide across eyes, 0.5 wide across hind margin of pronotum.

Colouration. Creamy white to pale yellow. Head concolorous with thorax; thorax creamy white with light yellow carina; tegulae concolorous with thoracic notum. Forewings hyaline, veins pale, apical margin bordered with black. Abdomen creamy white near base, near black distally (Fig. 3A-E). 

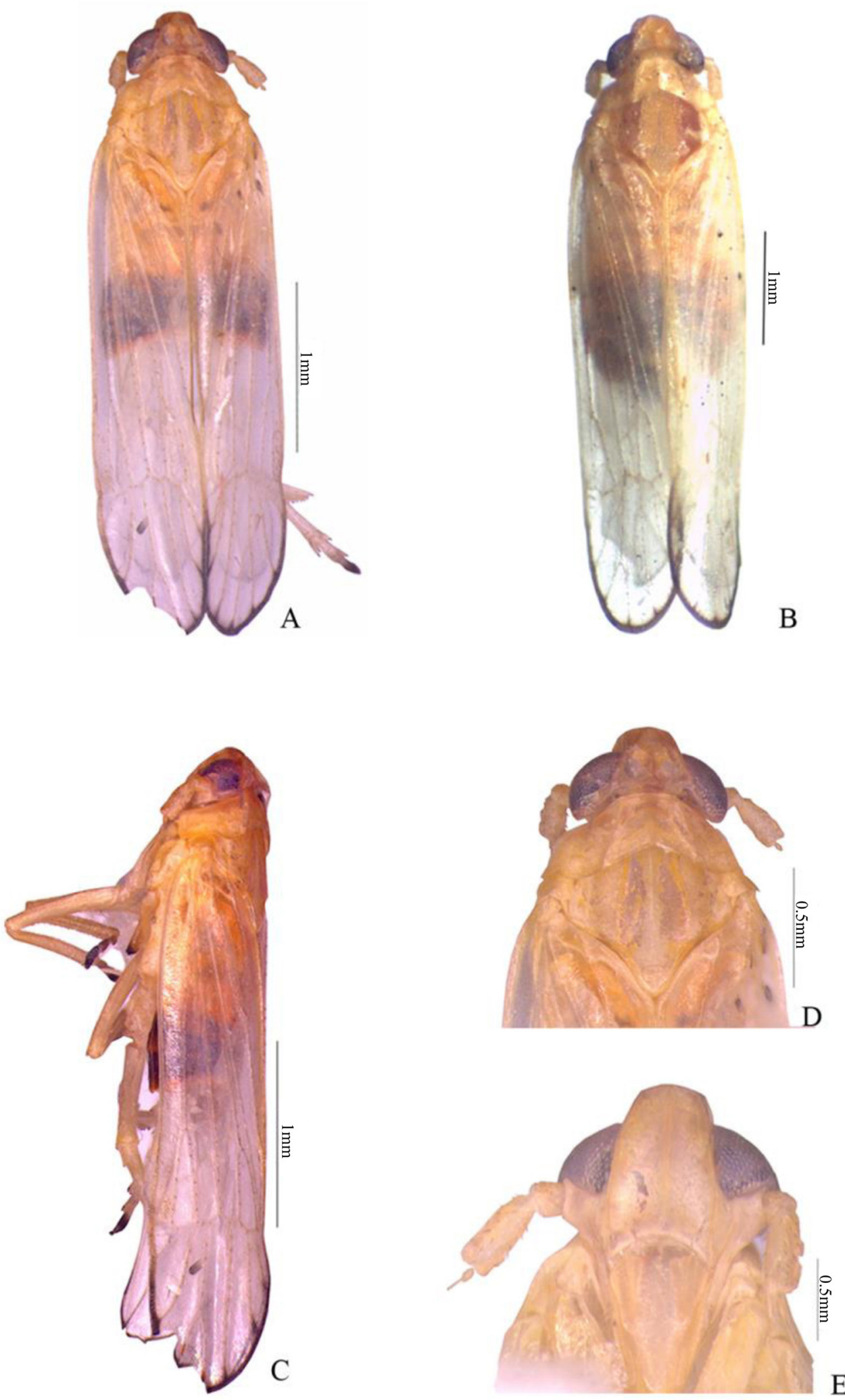

Fig. 3. Eoeurysa sagittaria sp. nov., habitus. A, C-D. Holotype $\widehat{\partial}$ (NPC HEMT9). B. Paratye $q$ (NPC HEMT14). A. Male habitus, dorsal view. B. Female habitus, dorsal view. C. Habitus, lateral view. D. Head, pro- and mesonotum, dorsal view. E. Head, ventral view. 

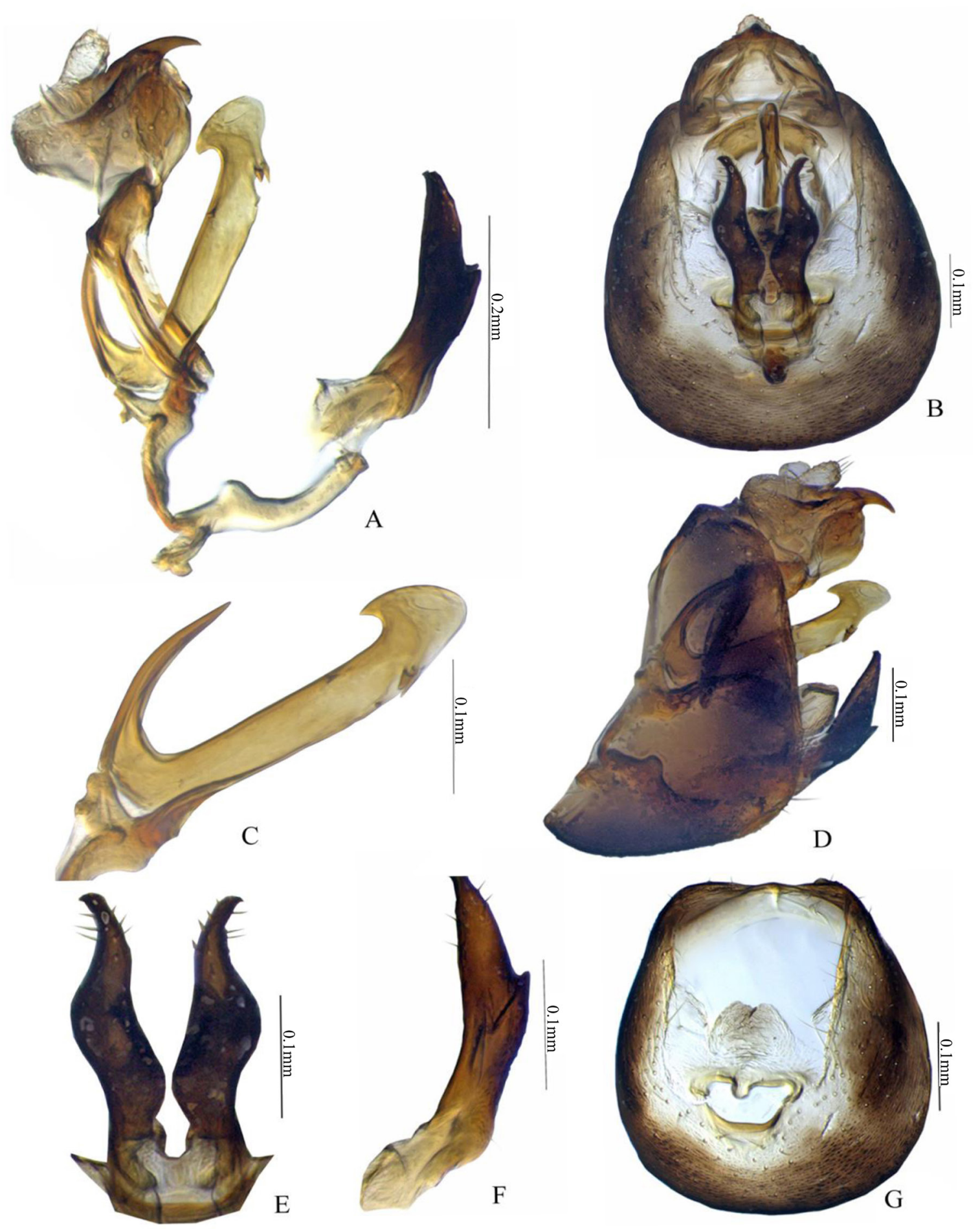

Fig. 4. Eoeurysa sagittaria sp. nov., male genitalia, holotype (NPC HEMT9). A. Aedeagal complex. B. Male genitalia, caudal view. C. Aedeagus. D. Male genitalia, lateral view. E. Parameres, caudal view. F. Paramere, lateral view. G. Pygofer, caudal view. 
Morphology. Body dorsoventrally depressed. Head including eyes $0.9 \times$ as wide as pronotum. Vertex broad, widest at base, tapering distally to broad apex; length $0.4 \times$ width across eyes, Y-shaped carina distinct, forked near distal margin of eyes (Fig. 3A, D ). Anterior margin of head weakly convex (from dorsal or ventral view), fastigium sharply angled (from lateral view) (Fig. 3C). Frons moderately broad, longer than wide, lateral margins weakly arced, widest subapically; median carina forked near fastigium. Carina of frons and clypeus prominent. Clypeus base as wide as apex of frons, rostrum reaching mesocoxae (Fig. 3E). Antennae terete, scape about as wide as long; pedicel approximately $3 \times$ as long as scape. Pronotum broad, $3.1 \times$ as wide as long; carinae distinct, lateral carinae reaching posterior margin. Mesonotum $1.1 \times$ as wide as long (Fig. 3D), with carinae not reaching posterior margin, lateral carinae weakly diverging posteriorly.

Male Genitalia (Fig. 4). Pygofer in lateral view roughly triangular (much wider ventrally than dorsally, dorsocaudal margins not expanded); in caudal view $1.2 \times$ as long as wide, medioventral processes of opening absent, diaphragm weakly sclerotized, moderately wide, dorsal margin convexly produced (Fig. 4D, G). Parameres simple (in caudal view), $8 \times$ as long as wide; sinuate with sharp, dorsolaterally directed apices (Fig. 4E); in lateral view with mediolateral process (Fig. 4F). Aedeagus tubular, straight, mostly of uniform width; $7.2 \times$ as long as wide; base with elongate caudally curved spine; apex abruptly broadened and decurved round sagittate apex, basally ornamented with long curved spinose process. Suspensorium elongate, ventral two-thirds ring-like (Fig. 4A, C). Segment 10 quadrangular, $1 \times$ as long as wide, ring-like, bearing short, curved processes on dorsocaudal surface; segment 11 moderately long (Fig. 4A, D).

Female Genitalia (Fig. 5). Valvulae I in lateral view (Fig. 5A), dorsally concave, dorsal and ventral margin with smoothly sculptured area extending from base to apex. Valvulae II (Fig. 5B), in lateral view, distal half of dorsal margin with 17-18 large, quadrangular, distantly placed serrations decreasing in size gradually towards the apex; apex acute with small serrations; ventral margin translucent, tip with few serrations.

\section{Molecular data}

The DNA barcode fragment ( $\mathrm{mtCOI} \sim 650 \mathrm{bp}$ ) sequence was submitted to NCBI GenBank with accession numbers MN787520 and MN787521.

\section{Remarks}

Eoeurysa sagittaria sp. nov. is closely related to E. arundina, especially based on the basal process of aedeagus (Fig. 4C). This species can easily be identified by the flattened body (Fig. 3A), the progressively broadening frons (Fig. 3D) and the structure of the male genitalia (Fig. 4) (aedeagus apically sagittate, lacking the dorsal teeth of E. arundina).

\section{Discussion}

Including the species described here, there are now 54 species of Delphacidae reported from India. Additionally, Mammen (1971) described 13 additional taxa in a thesis on Indian Delphacidae, but these names are not considered published in the sense of the International Code of Zoological Nomenclature (viz., ICZN 1999, online version article 9.12). This number undoubtedly underestimates the true diversity of delphacid species. In comparison, Costa Rica has 57 reported delphacid species (Bartlett 2019), nearly the same number reported from India, despite India being approximately $64 \times$ the size of Costa Rica. Additionally, the Indomalayan region has 467 known delphacid species, compared with 266 in the Neotropical region (Bartlett et al. 2018), further suggesting that the known delphacid fauna of India is greatly underestimated. 


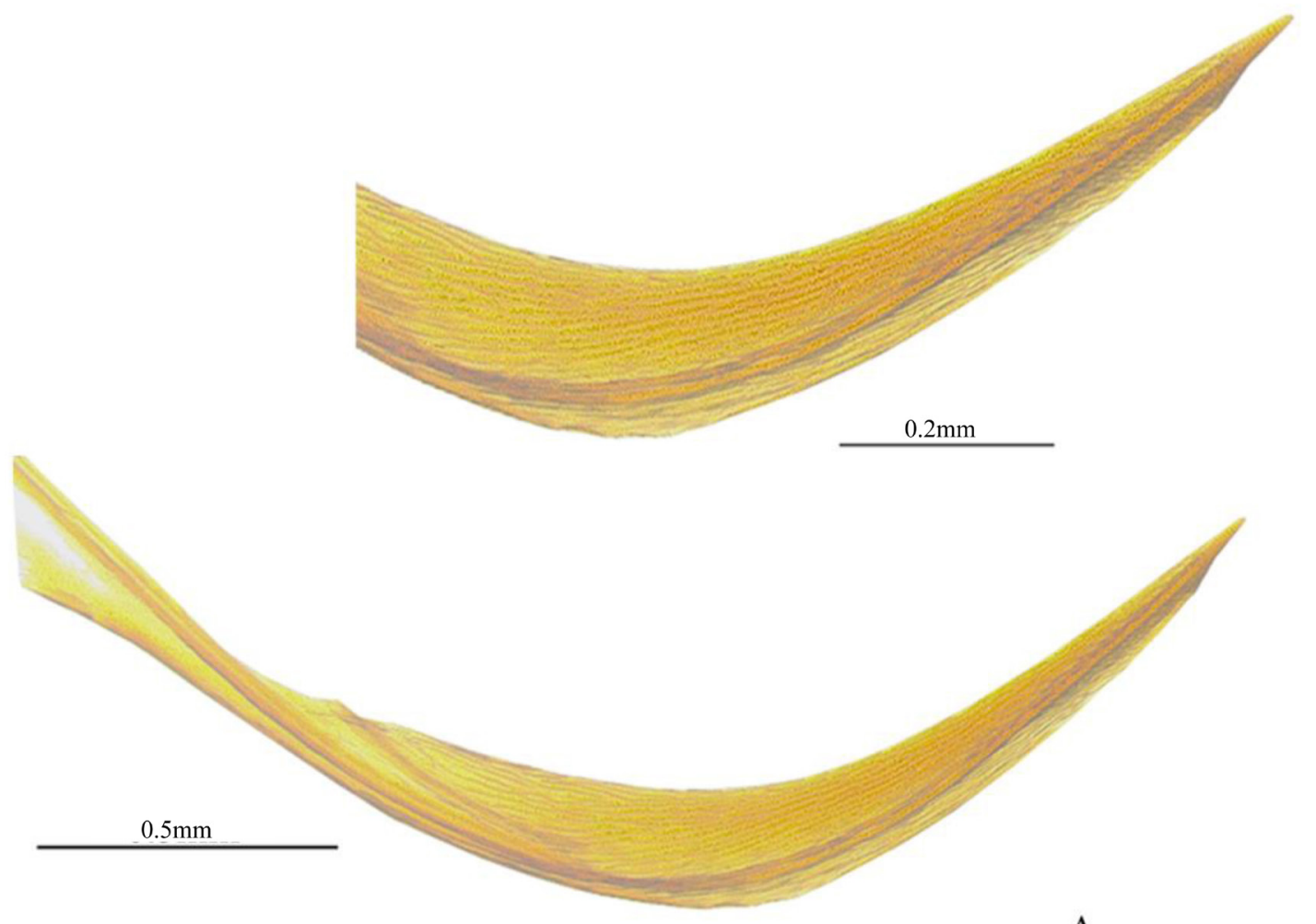

A

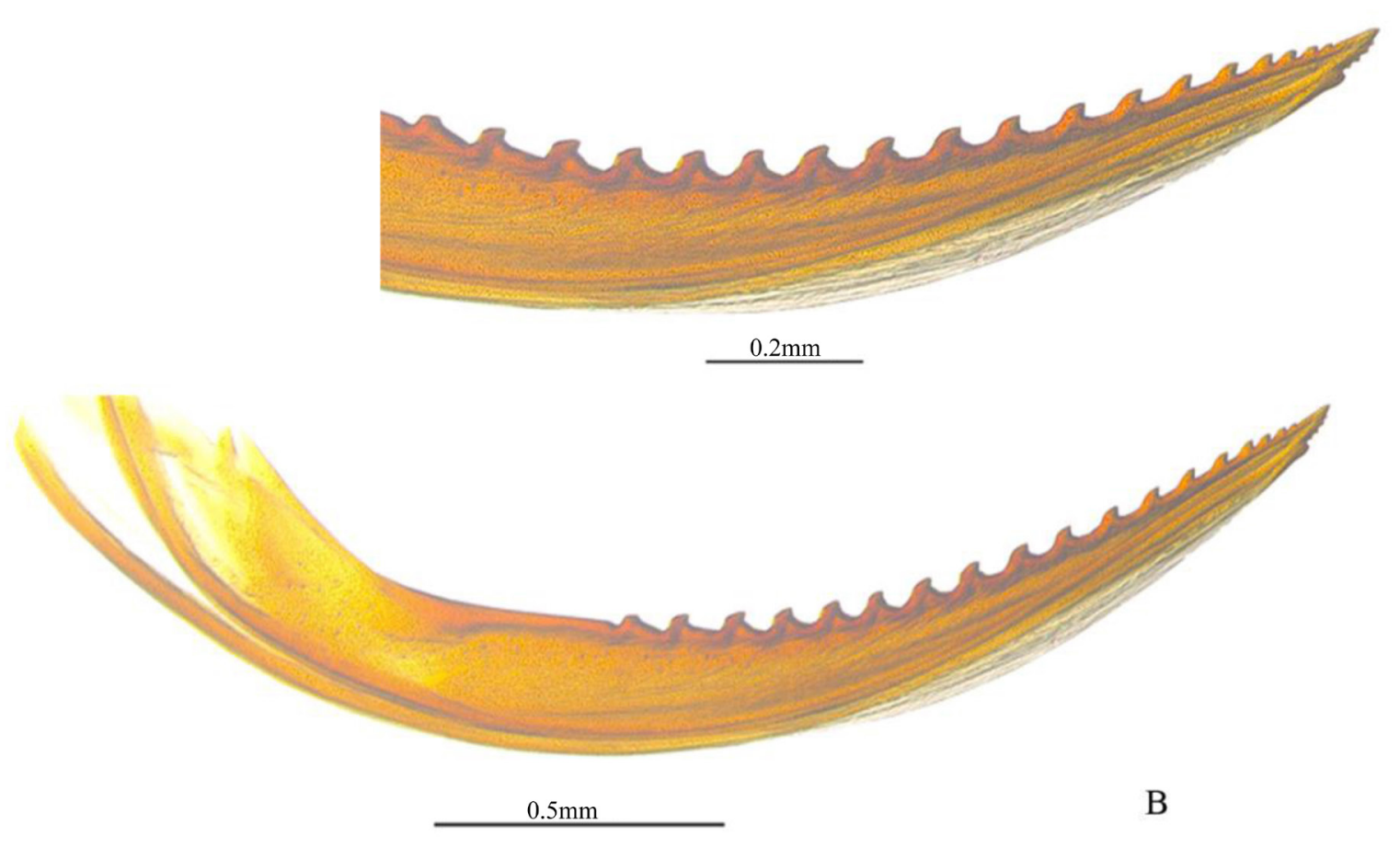

Fig. 5. Eoeurysa sagittaria sp. nov., female genitalia, paratype (NPC HEMT14). A. Valvulae I. B. Valvulae II. 
Here, we provide mitochondrial cytochrome oxidase subunit I (mtCOI) gene sequences for the new species, which act as reference sequences for the taxa and allow further molecular studies. This represents the first molecular data for the genus Parasogata. Additional data from mtCOI is needed to compare the species within Parasogata and Eoeurysa, and additional genes will be needed to comment on the evolutionary lineage and relationships of these with other genera within Delphacini. Blast searches of these mtCOI data for both species on both GenBank and Barcode of Life databases suggest that there is no similar data for closely allied delphacids available. Collection of additional delphacid species and mtCOI data from a variety of Delphacini would be desirable to improve DNA barcoding identification results.

\section{Acknowledgements}

The authors wish to thank Dr Debjani Dey, Head, Division of Entomology, and the Postgraduate School, ICAR-IARI, New Delhi for providing facilities used in this work. National Agricultural Higher Education Project - Centre for Advanced Agricultural Science and Technology (NAHEP - CAAST) for providing funding, and National Biodiversity Authority (NBA) Chennai, are greatly acknowledged. Also, the grant from Science and Engineering Research Board, Department of Science and Technology (EMR/2016/006582) is gratefully acknowledged. We also wish to thank Dr Bartlett's lab, Department of Entomology and Wild Life Ecology, College of Agriculture and Natural Resources, University of Delaware, Newark DE 19716, USA for necessary permissions and facilities provided.

\section{References}

Asche M. 1985. Zur Phylogenie der Delphacidae Leach, 1815 (Homoptera: Cicadina: Fulgoromorpha). Marburger Entomologische Publikationen 2 (1): 399-910.

Asche M. 1990. Vizcayinae, a new subfamily of Delphacidae with revision of Vizcaya Muir (Homoptera: Fulgoroidea) - a significant phylogenetic link. Bishop Museum Occasional Papers 30: 154-187.

Bartlett C.R. 2009. A new genus of new world Tropidocephalini (Hemiptera: Delphacidae: Delphacinae), with the description of two new species. Entomological News 120 (4): 387-396.

https://doi.org/10.3157/021.120.0407

Parasogata sexpartita sp. nov.

Eoeurysa sagittaria sp. nov.

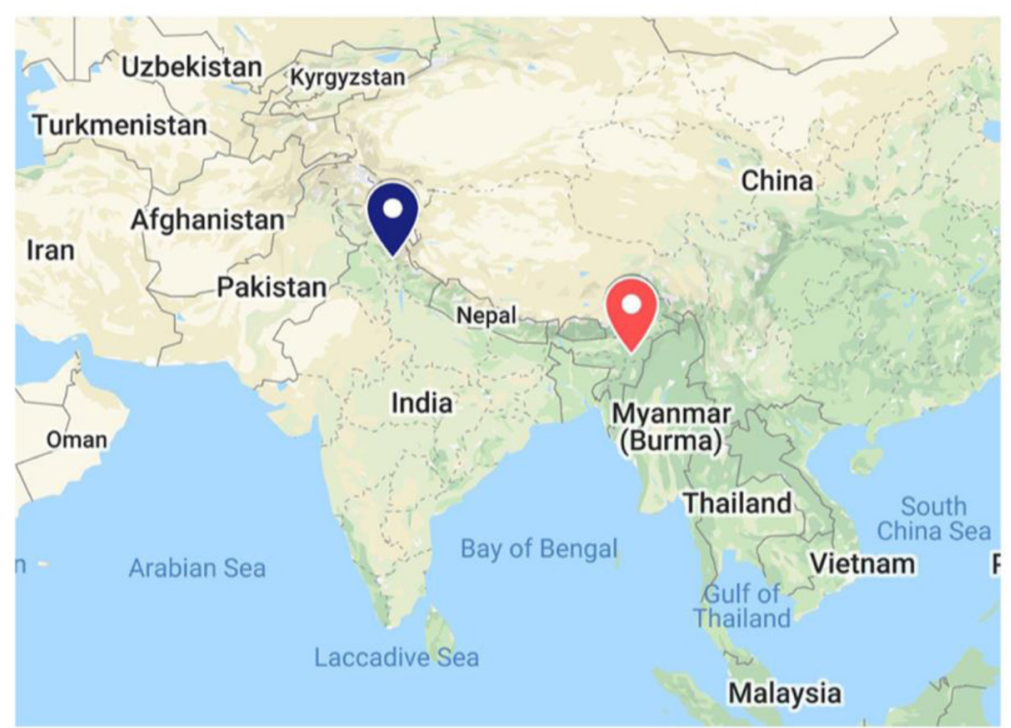

Fig. 6. Distribution map of the new species. 
Bartlett C.R. 2019. A new genus and species of Delphacidae (Hemiptera: Fulgoroidea: Delphacidae) from Costa Rica. Zootaxa 4657 (2): 361-368. https://doi.org/10.11646/zootaxa.4657.2.8.

Bartlett C.R., Deitz L.L., Dmitriev D.A., Sanborn A.F., Soulier-Perkins A. \& Wallace M.S. 2018. The diversity of the true hoppers (Hemiptera: Auchenorrhyncha). In: Foottit R.G. \& Adler P.H. (eds) Insect Biodiversity II: Science and Society: 501-590. Wiley-Blackwell, Chichester.

https://doi.org/10.1002/9781118945582.ch19

Bourgoin T. 2019. FLOW (Fulgoromorpha Lists on The Web): a world knowledge base dedicated to Fulgoromorpha. Version 8, updated 31 October, 2019. Available from http://hemiptera-databases.org/flow/ [accessed 6 Nov. 2019].

Chatterjee P.B. 1971. Occurrence of Eoeurysa flavocapitata Muir (Delphacidae) on sugarcane in India. The Indian Journal of Entomology 33: 220.

Chatterjee P.B. \& Choudhuri D.K. 1979. Biology of Eoeurysa flavocapitata - a delphacid insect pest on sugarcane in India. Entomon 4 (3): 263-267.

Datta B. \& Ghosh L.K. 1979. On Eoeurysa flavocapitata Muir (Homoptera: Delphacidae) from India. Bulletin of the Zoological Survey of India 2 (1): 99-100.

Dietrich C.H., Whitcomb R.F. \& Black W.C. 1997. Phylogeny of the grassland leafhopper genus Flexamia (Homoptera: Cicadellidae) based on mitochondrial DNA sequences. Molecular Phylogenetics and Evolution 8: 139-149. https://doi.org/10.1006/mpev.1997.0415

Dijkstra E., Rubio J.M. \& Post R.J. 2003. Resolving relationships over a wide taxonomic range in Delphacidae (Homoptera) using the COI gene. Systematic Entomology 28: 89-100.

https://doi.org/10.1046/j.1365-3113.2003.00203.x

Dijkstra E., Slotman M.A. \& Post R.J. 2006. Resolution of phylogenetic relationships of the major subfamilies of the Delphacidae (Homoptera: Fulgoroidea) using the mitochondrial ribosomal DNA. Insect Science 13: 167-177. https://doi.org/10.1111/j.1744-7917.2006.00079.x

Ding J.H. 2006. Fauna Sinica: Insecta, Vol. 45: Homoptera: Delphacidae. Science Press, Beijing. [In Chinese with English summary.]

Distant W. L. 1906. Rhynchota - Vol. III. (Heteroptera - Homoptera). In: Bingham C.T. (ed.) The Fauna of British India, including Ceylon and Burma: 1-503. Taylor \& Francis, London.

Hashmi T.R., Devi S.R.,Aahmad A., Meshram N.M. \& Prasad R. 2018. Genetic status and endosymbionts diversity of Bemisia tabaci (Gennadius) on hosts belonging to family Malvaceae in India. Neotropical Entomology 48 (2): 207-218. https://doi.org/10.1007/s13744-018-0639-y

Huang Y.X., Zheng L.F., Bartlett C.R. \& Qin D.Z. 2017. Resolving phylogenetic relationships of Delphacini and Tropidocephalini (Hemiptera: Delphacidae: Delphacinae) as inferred from four genetic loci. Scientific Reports 7 (1): 1-10. https://doi.org/10.1038/s41598-017-03624-w

International Commission on Zoological Nomenclature (ICZN). 1999. International Code of Zoological Nomenclature Fourth Ed. The International Trust for Zoological Nomenclature, London. Available from https://www.iczn.org/the-code/the-international-code-of-zoological-nomenclature/the-code-online/ [accessed 4 Nov. 2020].

Joseph A.N.T. 1961. Taxonomic notes on Sardia rostrata Melichar [Homoptera, Fulgoroidea, Delphacidae (= Araeopidae)]. Journal of Bombay Natural History Society 58 (1): 46-52.

Joseph A.N.T. 1964. A new species of Stenocranus: S. ajmerensis sp. nov. (Araeopidae: Fulgoroidea; Homoptera: Heteroptera). Journal of the Bombay Natural History Society 61 (2): 460-462. 
Kalode M.B. 1983. Leafhoppers and planthoppers of rice in India. In: Knight W.J., Pant N.C., Robertson J.S. \& Wilson M.R. (eds) Proceedings of the $1^{\text {st }}$ International Workshop on Biotaxonomy, Classification and Biology of Leafhoppers and Planthoppers (Auchenorrhyncha) of Economic Importance: 225-245. Commonwealth Institute of Entomology, London.

Knight W.J. 1965. Techniques for use in the identification of leafhoppers (Homoptera: Cicadellidae). Entomology Gazette 16: 129-136.

Kuoh C.L., Huang C.L., Tian L.X. \& Ding J.H. 1980. New species and new genus of Delphacidae from China. Acta Entomologica Sinica 23 (4): 413-426.

Mammen K.V. 1971. Studies on Indian Delphacidae (Homoptera). PhD thesis, Indian Agricultural Research Institute, New Delhi, India.

Mammen K.V. \& Menon M.G.R. 1972. New records of delphacids from India. Entomologists Newsletter 2: 7-9.

Muir F.A.G. 1913. On some new Fulgoroidea. Proceedings of the Hawaiian Entomological Society 2: 237-269.

Muir F.A.G. 1921. On some Delphacidae from South India (Homoptera). Proceedings of the Hawaiian Entomological Society 4: 480-486. https://doi.org/10.5962/bhl.part.16151

Nimisha K.K. 2008. Studies on planthoppers (Hemiptera: Delphacidae) occurring in different agroecosystems in Karnataka. MSc thesis, University of Agricultural Sciences, Bangalore, India.

Oman P.W. 1949. The Nearctic leafhoppers (Homoptera: Cicadellidae). A generic classification and check list. Memoirs of the Entomological Society of Washington 3: 1-253.

Ramya N. \& Meshram N.M. 2019. New record of the genus Bambusiphaga (Hemiptera: Delphacidae: Tropidocephalini) from India with description of a new species. Zootaxa 4658 (1): 197-200. http://dx.doi.org/10.11646/zootaxa.4658.1.13

Rao V.R.S. \& Chalam M.S.V. 2006. Biodiversity of planthopper fauna (Delphacidae: Hemiptera) associated with rice and sugarcane crop-ecosystems in South India. Hexapoda 14 (2): 129-141.

Sharma S.K. \& Singh S. 1980. A new species of Laodelphax Fennah (Fulgoroidea: Delphacidae) from North Western India. Indian Journal of Zoology 4 (1-2): 49-52.

Sharma S.K. \& Singh S. 1982. A new Indian species of Purohita Distant (Homoptera, Delphacidae, Fulgoroidea). Entomologist's Monthly Magazine 118: 23-25.

Urban J.M., Bartlett C.R. \& Cryan J.R. 2010. Evolution of Delphacidae (Hemiptera: Fulgoroidea): combined-evidence phylogenetics reveals importance of grass host shifts. Systematic Entomology 35: 678-691. https://doi.org/10.1111/j.1365-3113.2010.00539.x

Wilson M.R. 1987. A faunistic review of Auchenorrhyncha on sugarcane. In: Vidano C. \& Arzone A. (eds) Proceedings of the $6^{\text {th }}$ Auchenorrhyncha Meeting: 485-492. Consiglio nazionale delle ricerche, Turin.

Wilson S.W. 2005. Keys to the families of Fulgoromorpha with emphasis on planthoppers of potential economic importance in the southeastern United States (Hemiptera: Auchenorrhyncha). Florida Entomologist 88 (4): 464-481. https://doi.org/10.1653/0015-4040(2005)88[464:KTTFOF]2.0.CO;2

Wilson S.W. \& O'Brien L.B. 1987. A survey of planthopper pests of economically important plants (Homoptera: Fulgoroidea). In: Wilson M.R. \& Nault L.R. (eds) Proceedings of the $2^{\text {nd }}$ International Workshop on Leafhoppers and Planthoppers of Economic Importance: 343-360. Brigham Young University, Provo. 
Wilson S.W., Tsai J.H. \& Chen C.C. 1992. Descriptions of immatures of Eoeurysa flavocapitata Muir from Taiwan (Homoptera: Delphacidae). Pan-Pacific Entomologist 68 (2): 133-139.

Yang C.T. 1989. Delphacidae of Taiwan II (Homoptera: Fulgoroidea). NSC Special Publications 6: $1-334$.

Zhou Z.X., Yang L. \& Chen X.S. 2018. Parasogata gen. n., a new genus of the tribe Delphacini with descriptions of two new species from China (Hemiptera, Fulgoromorpha, Delphacidae). ZooKeys (806): 73-85. https://doi.org/10.3897/zookeys.806.26394

Manuscript received: 9 January 2020

Manuscript accepted: 17 September 2020

Published on: 23 November 2020

Topic editor: Nesrine Akkari

Section editor: Anna Namyatova

Desk editor: Radka Rosenbaumová

Printed versions of all papers are also deposited in the libraries of the institutes that are members of the EJT consortium: Muséum national d'histoire naturelle, Paris, France; Meise Botanic Garden, Belgium; Royal Museum for Central Africa, Tervuren, Belgium; Royal Belgian Institute of Natural Sciences, Brussels, Belgium; Natural History Museum of Denmark, Copenhagen, Denmark; Naturalis Biodiversity Center, Leiden, the Netherlands; Museo Nacional de Ciencias Naturales-CSIC, Madrid, Spain; Real Jardín Botánico de Madrid CSIC, Spain; Zoological Research Museum Alexander Koenig, Bonn, Germany; National Museum, Prague, Czech Republic. 